\title{
Gender and Pakpak Dairi Language Changes
}

\author{
Ida Basaria \\ The Lecturer of Cultural Studies \\ University of Sumatera Utara \\ Medan, Indonesia \\ ida1@usu.ac.id
}

\begin{abstract}
The shift or defense of a language is influenced by many factors. Industrialization and urbanization are seen as the main cause of the shifting of a language; in addition to the other factors such as small number of speakers, settlement concentration, and other factors that are often regarded as the cause of the shifting of a local language. This research examines Pakpak Dairi language; how the manner of women is different from men, even an imbalance between the male and female languages. It also observed whether the gender influences the shift and defense of Pakpak Dairi language. This study was conducted in Sidikalang, Dairi district. Location selection is based on the consideration of a multilingual situation with the presence of Bahasa Indonesian, Batak Toba language, and Karo language which used in social communication. Observations were made on two research sites consisting of (1) urban areas with more heterogeneous assumptions of language use in the domain of intermarriage and (2) the same area with more homogeneous assumptions of language use in the ethnic marital domain. This research utilizes qualitative ethnography method. Data collected by using scrutinize method, either by scrutinize with talking (SLC) or scrutinize without talking (SBLC). The result of the research proves that women of Pakpak Dairi have a strong influence on the defense and shifting of Pakpak Dairi language.
\end{abstract}

Keywords-Gender, Defense, Shifting, Multilingual

\section{INTRODUCTION}

In the language context in Indonesia, which is multilingual, multiethnic, and multicultural, with the contact intensity is quite high between ethnic groups one and the other, linguistic competition is inevitable. Moreover, if the competition is connected with the rapid development and progress of Indonesian language in almost every group of society. Symptoms of local language shifts are also manifestly demonstrated not only by the reduced interest of the younger generation to learn local languages as their regional identity but also increasing the tendency of parents who come from one tribe families to choose to use the Indonesian language (hereafter shortened to $\mathrm{BI}$ ) as their primary communication tool at home. It indicates that the domain of local language use in the household gradually began to be displaced by BI, which also has triggered the "language shift".

The most fundamental cause of language shift is probably the condition of bilingualism. Although this bilingual is not the only factor that causes the language shift. Because bilingualism does not necessarily cause a language shift, although this is one of the conditions for the language shift.
The cases of language shift are almost entirely through generation transfer (intergeneration).

In the final stages, language shifts will gradually lead to the extinction of the language. The extinction of minority languages, especially languages in developing countries concludes that the main reason for the extinction of languages is that parents no longer teach mother tongue to their children, and no longer actively use it at home in any communication domain (Grimes 2000 : 17). The extinction was not because the speaker stopped talking, but the choice of language use of most of the people them said (Landsweer 1999 : 1). Speakers choose not to speak the mother tongue to their children and choose not to use it actively in the realm of home conversation. The extinction of a language is also determined by the pressure of the majority language in a multilingual community. Choosing not to use the mother tongue, using a different language,and majority language pressure are three important factors causing language extinction.

Through the language event, Pakpak Dairi ethnic in Dairi district of North Sumatra is a multilingual society, because in fact the Pakpak community mastered the BI, Batak Toba language even Karo language. Basaria, (2016) mentions that Pakpak Dairi language (hereafter shortened to BPD) is one of the local languages in Indonesia, whose existence is also feared by many parties, especially the older generation, because it is thought to be threatened displace by BI usage and even by Toba Batak language (also Karo language) among the younger generation. This research report is intended to see how far the mother's role in this language change, whether it affects defense or impacts shifts.

Women are often identified with the second man, the second creation, marginalized, subordinated and other terms leading to the justification of the weak, powerless and incapable position of women. Traditionally, tradition only gives public access and becomes head of family (leader etc) to men and not to women. In the local cultural ethnic Pakpak Dairi by various circles referred to embrace patriarchal society system which places the father / man as the decision making, as well as a reference to any good decisions affecting both men and women. This research would like to answer how the attitude of the speakers of BPD on the family of miscegenation. Does gender have an effect on the change of BPD. 


\section{THEORETICAL FRAMEWORK}

In the sociolinguistic view, language is not only seen as an individual phenomenon, but it is a social phenomenon. As a social phenomenon, language and its usage is determined by linguistic factors such as social status, the level of education, age, economic level, gender, and nonlinguistic factors of the speaker, with what language, to whom, when, where, and on what issue.

This research is approached through libraries relating to language usage and choice, especially about the concept of gender, bilingualism, shifting and preserving language, domains, language attitudes. There are three of them that are important here: bilingualism, language competition, and language attitudes.

\section{A. Bilingual and Bilingual Speaker}

The term bilingualism is a term whose meaning is relative. Such relativity occurs because a person's limit to be called bilingual speaker is arbitrary and hardly determined with certainty. At first, bilingualism is defined as the ability to use two languages equally well by a speaker, which Bloomfield (1958: 56) formulated as native-like control of two languages. But the opinion is getting more and more unpopular, because there is no basis to determine the extent to which a speaker can "use two languages equally well", so it difficult to measure and almost impossible to do. Hence the notion of such bilingualism is then only seen as one of the only kinds of bilinguality.

In line with the development of the understanding of bilingualism, Haugen (1968: 10) put forward as knowledge of two languages. Such a formula is intended to show that in the bilingualism case, a bilingual speaker does not have to master two languages actively. It is enough a completely passive bilingualism, understanding without speaking. While Diebold (1968: 10) mentions the incipient bilingualism, namely the bilinguals experienced by people (especially children) who learns a second language in the early stages. At such a stage the bilinguality is still very simple and very low level. But this stage can not be ignored because at this stage lies the foundation of further bilinguality.

\section{B. Language Domain}

In sociolinguistics, the term domain can not be separated from bilingualism because the demands of the language choice or languages appropriate in accordance with socio-cultural norms in the community. In a stable bilingual society each language is associated with different domains usage. Fishman $(1964 ; 1972 a)$ proposes this concept to explain the behavior of language used in bilingual societies and simultaneously to see patterns of language shifting and retention in the community. Based on the concept, from a number of languages on speaker's language repertoire can be seen which language is always used in the interaction between groups and which language is always used for intergroup (Siregar et al, 1989: 23).

A domain is a group of speech situations. Situations in which the people involved in a conversation are family members, such as conversations between husband and wife, mother and child, brother and sister, included into the family domain. Social situations that belong to the family domain are usually found in the household environment.

In this social status, the participants are not so important than in other domain, and the role relations of the participants are determined by their respective positions as family members in a conversation, such as parent-child, fathermother, brother-sister, and others. The number of domains are varies according to the needs and circumstances of the communities studied so that the domains number can be anything.

\section{Language Attitude}

Language attitude is a psychological event and it is part of the attitude in general. Language attitudes represent the mental position or feelings of own language or the language of another. Based on it, language attitude is usually divided into two things, namely positive attitude and negative attitude.

A positive attitude is the enthusiasm attitude towards the language use (the language used by the group / community said where they are). Instead, if the characteristics have disappeared or weakened from a person or a group of community members, means a negative attitude towards a language has overwhelmed itself or that group. The lack of passion or encouragement to maintain the independence of the language is one of the markers of negative attitudes, that the loyalty of the language began to weaken, which could continue to disappear altogether.

Negative attitudes to language occur when a person or group no longer has a sense of pride in their language, and divert it to other languages that do not belong to them. It can be influenced by several factors, that is: political factors, ethnic factors, race, prestige, assume the language is too complicated or difficult and so on. Negative attitudes will also be more pronounced if a person or group does not have an awareness of the existence of a language norm. The attitude is apparent in their speech. They feel there is no need to use the language carefully, orderly, and follow the rules.

\section{Language and Gender Relations}

The relationship between language and gender can be realized in three kinds of relationships in the Graddol and Joan view (2003: 13), namely:

\section{1) Language reflects gender division}

Differences in social experience between men and women have a certain effect in language behavior. Language is seen as a reflection of society and as long as society views men and women differently, and unequal, the differences in the male and female languages will surely continue to exist (Coates in Graddol dn Joan, 2003: 13).

\section{2) Language creates gender division}

This view implies that language has an important role in the construction and preservation of gender division. The way of language used in various contexts of social life can project biases about men and women whose implications define the expected social role of men and women. This forms the 
opinion that the language and discourse in which humans engage can shape personality and social life.

3) Language and social structure are mutually influential

This idea shows how non-linguistic mechanisms are supported by linguistic features to maintain gender division. For exam ple, it can be seen how the language reproduces the traditional concepts of "femininity" and "masculinity". However, to see why these traditional conceptions are oppressive to women, social theories are necessary in relation to language.

TABLE 1. DIFFERENCE BETWEEN MASCULINE AND FEMINISTS IN TERMS OF EMOTIONAL AND INTELLECTUAL

\begin{tabular}{|c|c|}
\hline Male (Masculine) & Women (Feminine) \\
\hline $\begin{array}{ll}\text { - } & \text { Very aggressive } \\
\text { - } & \text { Not emotional } \\
\text { - } & \text { Independent } \\
\text { - } & \text { Can hide emotions } \\
\text { - } & \text { More objective } \\
\text { - } & \text { Not easily affected } \\
\text { - } & \text { Not easily wobbled } \\
\text { - } & \text { against the crisis } \\
\text { - } & \text { More active } \\
\text { - } & \text { gore frank } \\
\text { - } & \text { Rarely cry } \\
\text { - } & \text { More ambitious }\end{array}$ & $\begin{array}{ll}\text { - } & \text { Not too aggressive } \\
\text { - } & \text { More emotional } \\
\text { - } & \text { Not very } \\
\text { independent } \\
\text { - } & \text { It's hard to hide } \\
\text { emotions } \\
\text { - } & \text { More subjective } \\
\text { - } & \text { Easily affected } \\
\text { - } & \text { Easy to waver } \\
\text { - } & \text { More passive } \\
\text { - } & \text { Home-oriented } \\
\text { - } & \text { Less frank } \\
\text { - } & \text { Cry more often } \\
\text { - } & \text { Less ambitious, etc. }\end{array}$ \\
\hline
\end{tabular}

How does gender influence in this case masculine and feminine conception of Pakpak language defense.

\section{RESEARCH METHODOLOGY}

The population of this study are ethnic community members of BPD who live in the research location which located in Sidikalang district, who are $<10$ years old to 60 years old. The main data of the study were obtained from respondents' answers using survey questionnaires, in addition to data from ethnographic methods with involved observational techniques and interviews.

Populasi penelitian ini adalah anggota masyarakat etnik BPD yang tinggal di lokasi penelitian yang berada di kota kabupaten Sidikalang, yang berusia $<10$ tahun sampai 60 tahun. Data utama penelitian diperoleh dari jawaban responden yang diperoleh melalui kuesioner survei, di samping data dari metode etnografi dengan teknik pengamatan terlibat dan wawancara.

The survey questionnaire contains a list of self-report questions about the respondents' language use and choice as used by Gunarwan (1994) and Wilian who examine the Sasak language in Lombok (2010). Observations were made on two research sites consisting of (1) urban areas with more heterogeneous assumptions on the language use in the dominant family domain, and (2) the same area with more homogeneous assumptions of language use in the ethnic marital domain. This research utilizes qualitative ethnography method. The data were collected by using the scrutinize method, either by scrutinize with talking (SLC) or scrutinize without talking (SBLC). The result of the research proves that women of Pakpak Dairi society have a strong influence on the defense and shifting of BPD.

\section{DISCUSSIONS}

After the text edit has been completed, the paper is ready for the template. Duplicate the template file by using the Save As command, and use the naming convention prescribed by your conference for the name of your paper. In this newly created file, highlight all of the contents and import your prepared text file. You are now ready to style your paper; use the scroll down window on the left of the MS Word Formatting toolbar.

In this research context, we want to see whether gender in this case women in relation role as parent in family domain, has an influence on the survival or extinction of BPD.

Like other societies, in the social life of the Pakpak Dairi community, division of labor and role in the family between husband and wife. The family is a social unit that differentiates both husband and wife to complete each other and help each other. The sample of this research is family of Pakpak society which come from miscegenation, it means one of the couple's husband or wife comes from another ethnic. Thus, the sample of this study focuses on two objectives of observation. The first observational objective was to sample the families of miscegenation in which the husbands came from Pakpak ethnic; the second target is a sample of families miscegenation whose wives are from Pakpak Dairi ethnic. The use pattern of sample language on the first target, (husband comes from Pakpak Dairi ethnic) according to the role relationships are illustrated in the following table. The pattern of language usage is obtained based on the number of frequencies of language usage categories which is reported samples on each role-relationship for all family members, namely groups of parents and groups of children. In each group there are role-related relationships such as husband / wife, son, daughter and friends in the father's group, and father, mother, brother, sister, and friends in the group of children. 
TABLE 2. AVERAGE VALUE BY RELATIONS ON THE TARGET I

\begin{tabular}{|l|l|l|l|l|}
\hline No. & $\begin{array}{l}\text { Relationship- } \\
\text { role }\end{array}$ & $\begin{array}{l}\text { Elective } \\
\text { Average } \\
\text { Value }\end{array}$ & SD & $\begin{array}{l}\text { Language } \\
\text { Usage }\end{array}$ \\
\hline 1. & Husband & 3,17 & 0,64 & Equal \\
2. & (wife) & 3,55 & 0,75 & BPD/BI \\
3. & Son & 3,58 & 0,75 & More BI \\
4 & Daughter & 2,46 & 0,65 & More BI \\
& Friend/family & & & More BPD \\
5. & Child Group & 3,76 & 1,31 & \\
6. & Father & 3,79 & 1,31 & More BI \\
7. & Mother & 3,67 & 1,28 & More BI \\
8. & Brother & 3,64 & 1,28 & More BI \\
9. & Sister & 3,67 & 1,29 & More BI \\
& Friend/family & & & More BI \\
\hline
\end{tabular}

(1= always/almost always BPD; $2=\mathrm{BPD}>\mathrm{BI} ; 3=\mathrm{BPD}=\mathrm{BI}$; 4=BI $>\mathrm{BPD} ; 5=$ always/almost always $\mathrm{BI}$ ).

\section{Scalability $=100 \%$}

In the table above listed the average value for nine interlocutors, from husband (wife) to friends. In the list contents of friends / family category appears twice to distinguish friends or family within the child's environment. The average value illustrates that the language used to the husband/wife is the same number of BPD and BI (3.17). However, for children (son and daughter) the language used turned out to be more BI (to son 3.55 and to daughter 3.58). To friends/family in the parent group, BPD is more widely used than BI (2.46).

In the group of children, BI is mostly used for fathers (3.76) and mothers (3.79). Similarly, to brothers and sisters, the more widely spoken language is BI (3.67 and 3.64). BI is also more widely used than BPD in groups of friends/family (3.67).

How the implications of the display in table 1 above. It can be explained that for families in miscegenation, where the father comes from Pakpak ethnic. Indeed this language has begun to shift generally. In the group of children, in the house realm there has been a shift BPD to the BI. The children's language choice when communicating to their parents mostly uses BI rather than BPD.
Notes to the table above is the language choice used in the husband and wife group is 3.27; it means same amount of $\mathrm{BPD}$ and BI. Especially preferred language to friends/family more BPD than BI (2.35). The existence of patriarchy concept on ethnic Pakpak has given role, responsibility, function, and even the space in which men in the household have dominant powers. It also affects the 'dominance' of its ethnic language (BPD). Seen in groups of husband/wife (husband comes from Pakpak ethnic), language choice as much as BPD and BI, surely suggests the superiority of men (fathers) in their language choices. Although his wife is not a speaker of BPD, husband turns his superiority by always using BPD by 'trying to bequeath on BPD' in the realm of his household. It also appears in the language choice to friends/family, husband wife use more BPD $(2,46)$. So the dominance of gender in men (husbands) also have an impact in the dominance of the language choice.

Furthermore, the pattern use of the sample language on the second target (the wife comes from Pakpak Dairi ethnic), according to the relationship role can be checked as follows.

TABLE 3. AVERAGE VALUE BY RELATIONSHIPS ON TARGET II

\begin{tabular}{|c|c|c|c|c|}
\hline No. & $\begin{array}{l}\text { Relationship- } \\
\text { role }\end{array}$ & $\mathrm{M}$ & SD & $\begin{array}{l}\text { Language } \\
\text { Usage }\end{array}$ \\
\hline & Parent Group & & & \\
\hline 1. & Husband (wife) & 3,74 & 0,50 & More BI \\
\hline 2. & Son & 3,47 & 0,57 & More BI \\
\hline 3. & Daughter & 3,41 & 0,57 & More BI \\
\hline 4 & Friend/family & 3,04 & 0,50 & Equal \\
\hline & & & & BPD/BI \\
\hline & Child Group & & & \\
\hline 5. & Father & 3,75 & 1,08 & More BI \\
\hline 6. & Mother & 3,65 & 1,08 & More BI \\
\hline 7. & Brother & 3,75 & 1,08 & More BI \\
\hline 8. & Sister & 3,76 & 1,28 & More BI \\
\hline 9. & Friend/family & 3,57 & 1,10 & More BI \\
\hline
\end{tabular}

(1= always/almost always BPD; $2=\mathrm{BPD}>\mathrm{BI} ; 3=\mathrm{BPD}=\mathrm{BI}$; 4=BI $>$ BPD; 5= always/almost always BI).

Scalability $=100 \%$

The average value in the table above illustrates that the language used for husband/wife is BI more widely used than BPD (3.74). The language choice to children (sons and daughters) is also more BI (3.47 and 3.41). To friends in the parent group turned out BPD choices as much as in BI (3.04). 
Within the group of children, the BI has shifted the BPD, $\mathrm{BI}$ is mostly used for fathers and mothers (3.75 and 3.65). Similarly, to brothers and sisters, BI has shifted BPD in the home domain (3.75 and 3.76). Likewise the language choice to friends/family, BI is more widely used than BPD (3.57). What is an important note in this event? In miscegenation, where mothers come from Pakpak ethnic, pressure on BPD is getting bigger.

In ethnic Pakpak, tradition only gives power/head of family (to men and not to women). In the local ethnic culture of Pakpak Dairi is called adherents patriarchal community system by various circles which places father/man as the decision-making side, as well as a reference to any good decisions affecting both men and women. The dominant male culture on the one side and the subordinated women has formed a subordinate female stereotype.

In addition to being subordinated, women are weaker than men. Emotionally women are less aggressive, (male: very aggressive), not too independent (male: independent), women are affected easily (men: not affected easily); women are more passive (male: more active). These things also become the cause of women in their role as wife unable/powerless to maintain BPD in the house realm.

In each group in table 2 above, BI is more widely used than BPD. So BPD has begun to shift. In the group of parents to friends/relatives, the choice of BPD as much as BI (3.04). The number is quite 'surprising' because BPD and BI are mostly used. After traced, there are several non-linguistic factors that are thought to be the cause. One that can be explained is that the qualitative interaction of wives to their relatives was quite large. In interacting, BPD is more widely used; in addition to the interaction of friends/relatives of nonPakpak ethnic, BI is more widely used.

There is a popular opinion that language can be analogous to organisms and that hence every language has a 'natural' age range (Edwards, 1985: 48). This argument explains that all languages will die naturally, in addition to the language that dies because there is language killer (linguicide). Another opinion, now grateful is that language does have a certain age range, and it depends on the owners or the user of it. Its speakers are the ones who determine whether or not the language can survive. They are the keepers of their language to keep them sustainable and able to withstand the urge. A positive attitude toward their own language and their loyalty to their language will ensure their language will survive,

In the Pakpak Dairi ethnic, the concept as described above is very clearly illustrated. The domains of BPD usage run not as it is. Linguistic situations that do not work in accordance with these functions have a very real effect, especially on the resistance of BPD as an Indonesian regional language, which has greater demographic strength. In miscegenation family, the urgency of BPD is very worrying. Especially in miscegenation where women of Pakpak married men from outside ethnic, BPD's urgency is huge. As a weak side, wife is unable to bequeath the BPD to her children, because under the superiority of husband, wife unable to maintain language (read: BPD). Similarly, if men from Pakpak ethnic married non-Pakpak ethnic women, although the husband acts superiority and tries to bequeath the BPD, but inheritance of BPD is not running properly, because in the house realm, children are more 'socialize and communicate' with their mother (non-BPD ethnic) so so BPD inheritance ineffective.

\section{CONCLUSION}

Women of Pakpak Dairi ethnic have a strong influence on the defense and shifting of BPD. Women (in their role as wives) when married to men come from non-ethnic Pakpak, feared as the main cause of the destruction of BPD. Because as a weak side, the wife is not able to inherit BPD to his children, because it is under the husband's superiority. Likewise also if the men of Pakpak ethnic if married to women whom non-ethnic Pakpak, despite having superiority at home, but the inheritance of BPD is not working properly, at home, children are more 'socializing and communicating' with their mothers (non-ethnic BPD) so BPD inheritance ineffective.

\section{References}

[1] Abdullah. 1979. "Some Observation on Code-switching Among MalayEnglish Bilinguals" Makalah disampaikan pada RELC Seminar.

[2] Ball, P. 1983. "Stereotypes of Anglo-Saxon and Non-Anglo-Saxon Accent: Some Exploratory Australian Studies with the Matched Gaise Technique". Dalam Language Planning Sciences 2: 167-183.

[3] Basaria, Ida.2015. "Fungsi dan Relasi Gramatikal Bahasa Pakpak-Dairi : Kajian Tipologi Linguistik”.Tahun 1 dari Rencana 2.Tahun.. Lembaga Penelitian Universitas Sumatera Utara

[4] Basaria, Ida.2008. "Stereotip Gender dalam Bentuk Perintah Bahasa Batak Toba" Dalam Jurnal Penelitian Sosial Humaniora. Medan : Lembaga Penelitian USU :

[5] Basaria, Ida. 2016. "Seepage Diglossia Pakpak Dairi Language" Dalam Jurnal of Arts and Humanities

[6] Duran, R. (Ed.).). 1981. Lanno Language and Comunicative Behavior. Norwood, N.J. : Ablex Publising Corp.

[7] Edward J. 1985. Language, Society and Identity. Oxford: Basic Blackwell.

[8] Fasold, R. 1984. The Sociolinguistics of Society. Oxford: Basic Blackwell.

[9] Ferguson,C.A. 1972. "Sounding Some Topics in the Study a Language Attitudes in Multilingual Areas". Makalah pada The Tri-University Meetings on Language Attitudes, Yeshiva University.

[10] Fishman.J.A. 1964."Language Maintance and Language Shift as a Field Ofinquiry". Dalam Linguistics 9. [11] ${ }_{\text {House. }}$. 1972a. The Sociology of Language. Rowlwy, Massa Newbury

[12] 1 1972b. "The Relationship Between Micro and Macro sociolinguistics in thr Study of Who Speaks What LanguageWho and When". Dalam Priede and Holmes (Eds.): 15-32.

[13] ___ Et al. 1977.Bilingualism in the Barric. Blommington: India University.

[14] Gal, S. 1979. Language Shift Social Determinants of Linguistic Change in Bilingual Austria.New York: Academic Press.

[15] Gumperz,J. 1964. “ Hindi-Punjabi Code-switching in Delhi” dalam H.G. Lunt (Ed.). Proceedings of the Ninth International Congress of Linguistics". The Hague: Mounton.

[16] Gumperz, J. 1982. Discourse Strategies. Cambridge: CPU.

[17] Grimes, Barbara F.2002. Kecenderungan Bahasa untuk Hidup atau Mati secara Global (Global Language Viability): Sebab,Gejala, dan Pemulihan untuk Bahasa-Bahasa yang Terancam Punah". Dalam 
Bambang Kaswanti Purwo (Penyunting) PELBA 15. Jakarta:Lembaga Bahasa Atma Jaya

[18] Gunarwan,Asim.2002.Kasus-Kasus Pergeseran Bahasa Daerah:Akibat Persaingan dengan Bahasa Indonesia (makalah) dalam Jurnal Linguistik Indonesia. Tahun ke 24, No 1

[19] Halim, A. (Ed.) 1984. Politik Bahasa Nasional.Jilid 1 dan 2. Jakarta: Pusat Pembinaan dan Pengembangan Bahasa.

[20] Haugent, E. 1956.Bilingualism in the American: A Bibliography and Research Guide. Alabama: American Dialect Society.

[21] ___ 1973. " Bilingualism, Language Contact and Immigrant Languages in the United States: a Research Report 1956-1970”. Dalam T. Sebeok (Ed.). Current Trends in Linguistics 10. The Hague: Mounton.

[22] Hymes. D.1974. Foundations in Sociolinguistics. An Etnograpics Aprroach. Philadelpia: University of Pennsylvania Press.

[23] Ibrahim, Ali Ibrahim. 2011. Bahasa Terancam Punah: Fakta, SebabMusabab, Gejala dan Strategi Perawatannya Dalam Jurnal Linguistik Indonesia. Tahun ke 29, No 1

[24] Suwito. 1993. Sosiolinguistik Pengantar Awal. Surakarta: Henary Offset Solo

[25] Lubis, S, dkk. 1992. Sikap dan Pemakaian Bahasa Indonesia oleh Kelomppok Etnis Cina Kotamadya Medan. Naskah hasil penelitian.

[26] __ 1993. Language Maintance: Sebuah Studi Kasus tentang Pemertahanan Bahasa Etnis oleh Masyarakat Cina Medan. Naskah hasil penelitian.

[27] Labov,W. 1972. Sociolinguistics Patterns. Piladelphia: University of Pennsylvania Press.

[28] Lambert, W.E. et al. 1963. " Attitudinal and Cognitive Aspects of Intensive Study of a Second Language". Dalam Journal of Abnormal and Social Psycology 60: 44-51.

[29] Osgood, C.E. et al. 1957,1964. The Meansurement of Meaning Urban University of Illinois Press.
[30] Pelly, U. 1983. Urban Migration and Adaption in Indonesia: The Case Study of Minangkabau and Mandailing Batak Migrants in Medan, North Sumatera. Disertasi Ph. D. The University of Illinois.

[31] Smolicz, J.J. and R. Mal. Harris 1977. "Ethnic Language in Australia”. In International Journal of the Sociology of Language 14: 89-108.

[32] Siregar, B.U. 1988. " beberapa Aspek Sosiolinguistik dalam Pengajaran Bahasa”. Makalah dibacakan pada Kongres Bahasa Indonesia V. Jakarta.

[33] _ 1990. Etnografi Komunikasi: Ancangan Alternatif dalam Kajian Manusia dan Bahasa". Dalam Prosiding Seminar Nasiomal Peranan Perguruan Tinggi dalam Memasuki Era Pembangunan Abad XXI. Buku II. Medan: Universitas Sumatera Utara.

[34] 1991. "Pola Penggunaan Bahasa dan Sikap Bahasa Masyarakat Urban di Medan”: Laporan Penelitian. Medan: USU.

[35] . 1994. " Penalaran dalam Berbahasa: Gambaran Hubungan Keterikatan antara Kemampuan Berbahasa dan Pengalaman Sosiopsikologis". Makalah dibacakan pada Kongres Linguistik Nasional di Palembang, 1-5 Juni 1994.

[36] 1994. " Pengalihan Bahasa: Cerminan Perubahan Nilai Sosiobudaya di dalam Masyarakat". Makalah disampaikan pada Forum UM-USU di Kuala Lumpur, 20-22 Desember 1994.

[37] Taylor, D.M. et al. 1972. "Ethnic Identification in Canada: a Crosscultural Investigation". Dalam Canadian Journal of Behavioural Science 4: 13-20.

[38] Wardaugh. R. 1992. Introduction to Sociolinguistics. Edisi Kedua Oxford. Blackwell.

[39] Weinreich. U. 1953. Linguages in Contact. The Hague: Mouton.

[40] Williams. F. 1976. Exploration of the Linguistic Attitudes of Teachers. Rowley, Mass.: Newbury House.

[41] Solin, Matsyuhito.1998. Dalam Tradisi dan Perubahan : Konteks Masyarakat Pakpak Dairi. Medan : Monora. 